\title{
Womanspace: The underground and the labyrinth in Ursula K. Le Guin's Earthsea narratives
}

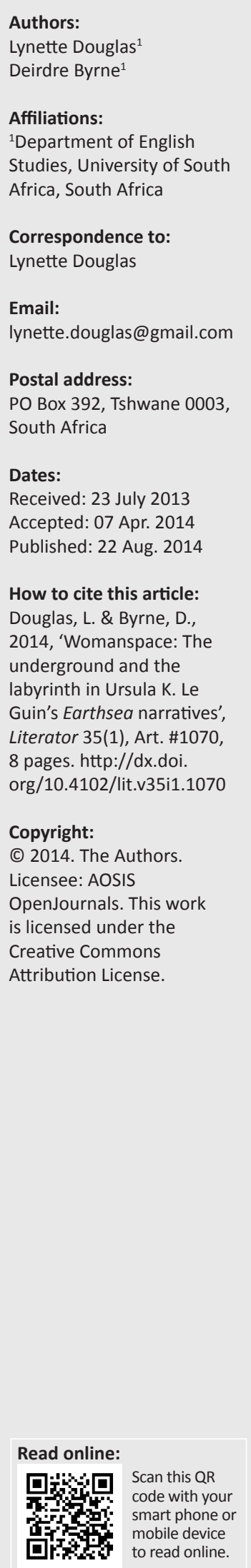

Ursula K. Le Guin's renowned Earthsea cycle, spanning 20 years and five texts, is often acknowledged to be a textual space for the creative exploration and interrogation of gender. The two spaces in the title - 'earth' and 'sea' - are held in equilibrium, both by the author's craft and by magic. Unfortunately, though, few critics have explored how these spaces function in the narrative. In this article, we explore the representation of underground spaces and labyrinths as meaningful landscapes in the Earthsea cycle. These spaces are found throughout Le Guin's Earthsea fiction, but are foregrounded in four narratives: 'The finder' and 'The bones of the earth' (Tales from Earthsea), The tombs of Atuan and The other wind. Le Guin's writing consistently identifies the earth as feminine, in keeping with the archetype of 'Mother Earth', and we find that subterranean spaces and labyrinths are depicted as sites of power and empowerment for women. Nevertheless, we argue that Le Guin's affinity for gender equity and balance prevents these tropes from becoming another tired revisioning of an easy equation of earthy forces and 'the feminine'. Rather, for Le Guin, the underground and the labyrinth are sites of union between masculine and feminine elements and characters, through the empowerment of the feminine.

Vroueruimte: Die onderwêreld en die labirint in Ursula K. Le Guin se Earthsea-narratiewe. Ursula K. Le Guin se beroemde Earthsea-reeks, wat strek oor 20 jaar en vyf tekste, is alombekend as 'n tekstuele ruimte vir die kreatiewe eksplorasie en kritiese ondersoek van gender. Die twee ruimtes in die titel - 'aarde' and 'see' - word in ekwilibrium gehou, beide deur die outeur se skeppingsvermoë en deur die bonatuurlike magie. Ongelukkig, het min kritici egter aandag gegee aan hoe hierdie ruimtes in die narratiewe funksioneer. In hierdie artikel ondersoek ons die voorstelling van ondergrondse ruimtes en labirinte as betekenisvolle landskappe in die Earthsea-reeks Hierdie ruimtes word deurgaans in Le Guin se Earthsea-fiksie aangetref, maar word in die volgende vier narratiewe vooropgestel: 'The finder' en 'The bones of the earth' (Tales from Earthsea), The tombs of Atuan en The other wind. Le Guin se skryfwerk identifiseer konsekwent die aarde as vroulik ooreenkomstig die argetipe van 'Moeder Aarde'. Voorts vind ons dat ondergrondse ruimtes en labirinte uitgebeeld word as posisies van mag en bemagtiging vir vroue. Nogtans, argumenteer ons dat Le Guin se affiniteit met gendergelykheid en -balans verhoed dat hierdie trope maar net nog 'n uitgeputte hersiening is van 'n maklike gelykstelling van aardse kragte en 'die vroulike'. Vir Le Guin, is die ondergrondse netwerke eerder ruimtes vir die vereniging van die manlike en die vroulike elemente en karakters deur die bemagtiging van die vroulike.

\section{Introduction}

Beneath the islands and seas of Ursula le Guin's fantastical world of Earthsea lies a network of tunnels and caves, hidden and forgotten, feared and evaded. This fascinating underworld space includes caves and labyrinths. It is first introduced in The tombs of Atuan (1974) and later revisited in Tales from Earthsea (2001) and The other wind (2001), but it has received scant critical attention. This is a pity, since Le Guin uses these spaces as symbolic references for her critical investigation of the place of women's power and magic in the world of Earthsea. Scholarly discussions of underground spaces and labyrinths generally explore these sites as repositories for unconscious emotions. ${ }^{1}$ Greer Gilman is one of the few to comment on the labyrinth that holds Tenar in her adolescence. In her article, 'Girl, implicated' (Gilman 2009:200), she describes The tombs of Atuan as one of the darkest labyrinth stories, and rightly explains that for Tenar 'the labyrinth becomes her only self, her privacy, possession, and the narrowest of liberties. Her inscape'. We believe, by contrast, that this narrow liberty is not nearly as negative or as disappointing as Gilman finds it. In keeping with the labyrinth's traditional function as a site for rebirth and renewal (Cooper 1978:93), Tenar discovers her true name and identity and emerges as a woman from the

1.Ben Stoltzfus (1981:292-307), in an article discussing Robbe-Grillet's use of labyrinths, typifies this trend when he observes: 'If Kafka's labyrinths create an anguish verging on despair, Borges' labyrinths evoke fear and the mystery of being'. 
labyrinth. The names she possesses on her emergence signal her disparate identities: she is Arha the High Priestess of the tombs, the eaten one whose being has been destroyed by the old powers, but she is also Tenar, the one who gives life to the wizard Ged when he transgresses the conventions of the Place. Tenar finds her own transformative power as a woman in the tombs in her encounter with Ged. This is the power of women that men in Earthsea have denied and repudiated, but it is essential to the life of its inhabitants.

Gilman considers Tenar's life after she leaves the tombs to be limited and believes that Tenar should have found her own way out of the labyrinth, without Ged's help. For her, Ged's presence in the labyrinth is a violation, for as she says, 'the girl in the labyrinth charts her own way out of it, driven by her curiosity and courage' (Gilman 2008:200). Gilman betrays her own essentialist bias by arguing that Tenar 'should' have found her way out of the labyrinth on her own. We contend, by contrast, that Tenar's courage is not compromised by her interaction with Ged, and that in this relationship Le Guin establishes a dialectic synthesis between masculine and feminine forces that is the foundation of social harmony.

T.S. Miller's (2011:27) article, 'The two kings and the two labyrinths: Escaping escapism in Henson's Labyrinth and Del Toro's Laberinto' mentions the pervasive symbolism of the labyrinth: 'this trope holds a particularly ancient place in narrative art generally, or perhaps even a ubiquitous one', but the rest of his article focuses more on the fantastic than on the resonances of the labyrinth. The lack of commentary on a symbol that permeates the Earthsea trilogy, and is reintroduced in the later revisioned narratives, deserves to be redressed. Our article demonstrates how the power of women is connected to these underground spaces. Although Le Guin does not use the labyrinth in precisely the same way as subterranean spaces, these two versions of the realm under the ground are both susceptible to similar gendered interpretations. Moss, the village witch of Re Albi, illustrates the subterranean foundation of women's magical power when she says: 'I have roots, I have roots deeper than this island. Deeper than the sea, older than the raising of the lands. I go back into the dark' (Le Guin 1993a:528). This statement shows clear affinities with second wave feminism's emphasis on the distinctive nature of women's psyche and abilities.

\section{Le Guin and feminism (again)}

Le Guin's Earthsea is presented as a patriarchal society in which the power of women is considered weak and wicked. ${ }^{2}$ A non-essentialist third-wave feminist approach, ${ }^{3}$ which Amy M. Clarke (2010) claims Le Guin shares, would not do justice to this inequity. We believe that, for Le Guin, women need to be considered as a separate and identifiable

2.In Earthsea, men want to keep for themselves the power inherent in the language of the making. So they withhold its knowledge from women and, therefore, the social hierarchy fails to recognise the true nature of women. The holding back of social hierarchy fails to recognise the true nature of women. The holding back of the words of power from women leads to the charms and spells they develop being inadequate and incomplete, which is why the phrases 'weak as women's magic' and wicked as women's magic (Le Guin is discussed by Douglas (2012) and Donaldson (2012:134).
This state of affars

3.Third-wave feminist thinkers include Judith Butler (1990), Gloria E. Anzaldúa (1987) and Donna Haraway (1985). constituency, not just as a segment of humanity, if a genderequitable society is to be achieved. To do so, as third-wave feminism occasionally does in its eagerness to deconstruct all identities, is to deny the political implications of gender altogether. ${ }^{4}$ This is a profound error of judgement in light of the ongoing violations of women's and children's rights in societies across the globe. Le Guin's fiction has significant affinities with second wave feminism in that she advocates not for the removal of gender difference, but for a complete overhaul of existing power structures in order to arrive at a more equitable dispensation with regard to gender. Whilst some critics have suggested that Le Guin's feminism falls into third wave post-feminism, our careful examination of the symbolism of labyrinthine and underground spaces in Earthsea will reveal a closer affinity between Le Guin and second wave feminists, such as Mary Daly, Mary Douglas, Carol Gilligan and Adrienne Rich. Whilst acknowledging that later theorists have challenged second wave feminism's tendency to essentialise women, we believe that some of the tenets of this movement, such as the political unification of women and the universality of patriarchal oppression, are still valid. Second wave feminists believe that certain innate qualities are associated with womanhood. Furthermore, they consider that a close link exists between the power of women and the trope of the earth. In light of their insights, this article uses a close gendered reading of Le Guin's labyrinths and underground spaces in order to examine the symbolism of the womb-tomb and the connection between female power and the earth. Freud (1913:169) claims that, in dream-symbolism, 'small boxes, chests, cupboards, and ovens correspond to the female organ; also cavities, ships, and all kinds of vessels'. An orthodox Freudian reading of the symbolism of caves and labyrinths would interpret these spaces and openings as analogues for female genitalia. We agree with Freud that these sites possess feminine qualities, but we read the spaces they enclose, not as signifying a lack of solidity, but as filled with potential for transformation. In this sense, our reading is more archetypal than sexual.

\section{'Mother Earth' as the source of women's magic}

Le Guin's Earthsea stories explore elements of earth magic, the powers the earth itself seems to hold in its old mythical connotations and its relationship with female power. The groundwork (the pun is intentional) for this exploration is laid in 'The bones of the earth'. 'The bones of the earth', set in Gont's imagined past, has not received much critical attention, but offers insight into the relationship between the Old Powers and women's magic and thus into the gendering of magic in the Earthsea cycle. The story narrates how the mage, Dulse, saves Gont from destruction by an earthquake

4.Linda Hutcheon (1993) explains the distance between a feminist and a postmodernist political agenda aptly when she says: 'The many feminist social agendas demand a theory of agency, but such a theory is visibly lacking in postmodernism, caught as it is in a certain negativity that may be inherent in any critique of cultural dominants' (p. 22)

5.We are aware that in Tehanu and The other wind, as well as the story 'Dragonfly' in Tales from Earthsea, Le Guin associates women with the elements of air and fire through the figure of the dragon. A full discussion of this trope is beyond the scope through the figure of the dragon. A full discussion of this trope is beyond the scope
of this article. We do not believe, however, that this association negates the link between women and the earth, which we explore here. 
through the lore that he has learned from his mentor, Ard. Le Guin reveals, quite late in the story and almost incidentally, that Ard is a woman. As Dulse is explaining to Ogion what will save Gont, he mentions:

\section{'She didn't say where she'd learned it.'}

'She?'

'Ard. My teacher.' Heleth [Dulse] looked up, his face unreadable, its expression possibly sly. 'You didn't know that? No, I suppose I never mentioned it. I wonder what difference it made to her wizardry, her being a woman. Or to mine, my being a man.' (Le Guin 2001:168)

It is noteworthy that Dulse, in the patriarchal Earthsea where wizards disparage women's magic, sought the mentorship of a woman. The deepest secrets he learned from her, secrets drawn from the depths of the earth, enable him to perform his greatest feat of magic and save Gont from destruction. Significantly, Dulse views magic as gender neutral, believing that the coming together of male and female magic creates a symbiosis that sustains life. He questions the rigid separation that Roke has imposed between men and women. He wonders what difference separates male and female magic and concludes that such diversity ought to be celebrated and explored, not dismissed and ignored. Whilst we applaud Dulse's balanced approach to the gender hegemony of magic in Earthsea, his view of the equality of men's and women's abilities does not address the power imbalances that have arisen from distancing these two forms of magic. He does not consider male or female magic more powerful or greater than the other. To him, masculinist ideology, through its fear of the power of women, seeks to undermine and banish the beauty and strength of female magic and has lost something valuable. Without this magic, Gont would be lost. Melanie Rawls (2008), in one of the few articles to comment on Tales from Earthsea, observes:

It is Ard's knowledge, passed without prejudice to a man, that saves the people of Gont from destruction. But she is not known and her knowledge of the Old Powers of the Earth are considered deeply suspect and transgressive. (p. 137)

Whilst Dulse is pondering the need to use Ard's lore, which reaches into the depths of the earth itself, to save the island, he recalls that her knowledge consists of 'strange matters, so strange he had never known if they were true wizardry or mere witchery, as they said on Roke' (Le Guin 2001:161). The misogynist mages on Roke have created an artificial distinction between 'true wizardry' and 'mere witchery' and so have lost opportunities to wield significant powers.

Faced with a destructive earthquake, Dulse and Ogion, guided by the teachings of Ard, who functions as a prototype of women's magic through her connection to the earth, implicit in her name, ${ }^{6}$ reach back to the old powers that Le Guin, throughout the Earthsea cycle, has associated with the power of women. Dulse describes this magic to Ogion as dirty magic (Le Guin 2001:167) because it deals with the dirt and rocks of the earth, elements that men's magic has chosen

6.'Earth' in Dutch is aarde, in Swedish is jord and in German is erde. As these transliterations indicate, Ard's name signifies her existential and professional connection to the earth. to ignore; the term 'dirty' in itself carries gender implications that bespeak the way patriarchy sidelines the power of women. Magicians and wizards, who by definition are men, do not like to get dirty. Dirt is related to the messiness of blood and menses, which is considered women's stuff, earthy matter, left to the village witches to deal with. It is related to the empty tomb where all matter is left to rot and disintegrate. These are hidden matters, left underground and buried out of sight. In exploring why authoritarian societies consider dirt dangerous, Mary Douglas explores the character of dirt, derived from a long process of discarding unwanted bits, which disintegrate and rot. She says:

Dirt was created by the differentiating activity of the mind, it was a by-product of the creation of order. ... Formlessness is ... an apt symbol of beginning and of growth as it is of decay. (Douglas 1966:198)

As Douglas's statements indicate, rubbish heaps are unpleasant and chaotic. They do not seem to possess power; they produce humus, which has the potential to nurture life in the same way as, when a man seems to die 'the little death" ${ }^{7}$ as he releases his sperm into the womb of a woman and feels temporarily depleted, there is the possibility of life from the 'death'. However, men in Earthsea, as in our societies, have avoided the depths and darkness because of their fear of the unconscious and of women, which are outside their control. Men's magic, through wizardry and magery, seeks the power to control the world (Le Guin 1993a:48) and they do not understand that women's magic does not seek control.

Ogion asks if the magic that Dulse has learned from Ard will control the earth itself (Le Guin 2001:167), but the power of women, rooted deeply in the earth, does not seek to master or control the elements. It reaches back to the oldest of powers deep in the darkness and works in conjunction with the earthly powers. Elehal, one of the earliest of the great women of power in Earthsea, tells Otter: 'women's powers are suspect, because [men] suppose them all connected with the Old Powers. As if those Powers were to be controlled or used by any mortal soul!' (ibid:85). In a similar vein, Dulse tells Ogion that the way to control the earthquake is 'more a matter of getting in with it, I think. Inside' (ibid:167). In this spirit, Dulse opens up the earth and enters into its depths. He finds the centre of the earthquake and stills it. So, by using the magic of women, he transforms himself into the bones of the earth and saves Gont from destruction.

Ard's lore has been neglected and the underground places Dulse enters have long been hidden because the male symbolic order in Earthsea has sought to malign and decimate all signs of women's magic. Places such as the cave at Aurun (Le Guin 2002:170), where the Old Powers were once sought for their wisdom, have similarly been abused. They are now neglected and turned into rubbish dumps, desecrated, although traces of their legendary powers remain in the Pelnish lore. When Alder seeks relief from the danger of his dreams of the dead,

7.The French phrase la petite mort is a euphemism for orgasm and is 'a popular reference for a sexual orgasm. The term has been broadly expanded to include reference for a sexual orgasm. The term has been broadly expanded to include
specific instances of blacking out after orgasm and other supposed spiritual releases specific instances of blacking out after orgasm and
that come with orgasm' (Urban Dictionary 2006). 
he is offered help by Seppel, a wizard of Paln, who takes him to the cave at Aurun:

Because it's not I but the Earth that will help Alder. Aurun is a sacred place, full of power. Although the people of Havnor have forgotten that, and use it only to defile it. (Le Guin 2002:170)

It is significant that Earth is given a capital letter here. It is personified as a place that possesses character, power and holiness, where healing powers can be found when needed. Like all places of the earth, it is also a place of transformation, a place where roots go deep, seeds are sown and change occurs. As discarded, dirty elements encounter the living tomb, they magically take on a new shape and emerge restored and whole, changed and healed, bearing life. There is, therefore, a connection between the underground cave at Aurun and the feminine power to bring forth life. No matter how it has been neglected, suppressed and thwarted, the power still exists.

As Alder surrenders to the power of the earth, yielding to the darkness and losing rational control of his own power, he finds the peace and freedom that he has desired. He is transformed in the darkness of the womb of the earth. He discovers that one needs to die before one can be reborn (Le Guin 1993a:273). In the incidents at Aurun and on Gont, Le Guin reminds us that although the structures of patriarchal society have negated and derided woman's power, there are men who are willing to cooperate with and revere that power.

\section{The ambivalence of women's power: Womb and tomb}

In 'The bones of the earth' and in Alder's experience at Aurun Le Guin illustrates a connection between the womb and the tomb, which foregrounds the ambivalence of women's magic. Dulse's death brings life to Gont. Alder is transformed at Aurun. Adrienne Rich, in discussing ancient civilisations that revered the Earth Mother explains how 'out of the earthwomb vegetation and nourishment emerged, as the human child out of the woman's body' (Rich 1995:107-108). This is further demonstrated in another story in Tales from Earthsea, 'The finder'.

The ability of women to transverse the inner and outer spaces of their own bodies through pregnancy is suggestive of a kind of permeability, such as Anieb shows when she visits Otter in his prison cell and later seems to be with or in him when he confronts Gelluk. Because women have an inner space, they appear to have the propensity, physically and metaphorically, to be able to receive things into themselves. This physical ability seems to mimic the emotional and relational skills often associated with women: to take in those who are hurting and to nurture and transform the brokenness into life, enabling a new identity to emerge. Rich (1995:64) postulates: 'Far from existing in the mode of 'inner space,' women are powerfully and vulnerably attuned both to 'inner' and 'outer' because for us the two are continuous, not polar'. The continuity between inner and outer space is observed in the symbolism of the earth as alive, and in the connection that women have with the earth and earth(l)y magic.

Through his interactions with Anieb, Otter learns that the magic of women must work in conjunction with men's power. With Anieb in him and guiding him, Otter leads Gelluk, the epitome of a patriarchal mage, to a place that has not been damaged by Gelluk's perverted search for mercury, defined by him as the AllKing, the perverted seed and semen of life (Le Guin 2001:26). There they lure Gelluk into opening the ground that Gelluk has abused and called the vile Red Mother earth' (ibid:260). He creates his own tomb, but for him there is no womb, no hope for life.

As Gelluk falls into the dark tomb of the cavern that opens up before him, Otter calls on the earth to close over him:

'Close, Mother! Be healed, be whole!' he pleaded begging, speaking in the Language of the Making words he did not know until he spoke them. 'Mother, be whole!' he said, and the broken ground groaned and moved together, healing itself. (Le Guin 2001:40)

It is highly significant that Otter calls to the earth as mother. Whilst the earth as mother is an archetype derived from classical mythology, ${ }^{8}$ it would be facile and, we believe, a trivialisation of Le Guin's employment of symbolism and metaphor to consider that she is simply using the archetype without thought or care. The earth mother is one of the oldest known symbols of identification with a deity. The fullness and capaciousness of the original shapes that identified the earth mother echo the form of the earth, and, although they came to be perceived largely as ugly in patriarchal societies, Rich (1995:93) suggests that they express 'an attitude toward the female charged with awareness of her intrinsic importance, her depth of meaning, her existence at the very centre of what is necessary and sacred'. Nevertheless, the image of earth as mother appears only in 'The finder', and in this story she is seen in a non-nurturing role, killing a cruel and tyrannical wizard. But Anieb guides Otter into the earth years later. There, she counteracts Gelluk's patriarchal role, functioning as a conduit for both maternal energy and earth power.

Years later, Otter returns to Havnor. He finds himself, whilst running from the wizard early, near Samory where the wizard Gelluk had died. In a scene parallel to that in which he had called on the earth to close over the cruel wizard, he now calls:

'Mother, open to me.'

He laid his hands on the seam of earth, but there was no power in them.

'Let me in, mother,' he whispered in the tongue that was as old as the hill. The ground shivered a little and opened.

He heard an eagle scream. He got to his feet. He leapt into the dark. (Le Guin 2001:98)

8.In Greek mythology, Gaia, the goddess of the earth, was also known as 'mother of all' and 'Mother Nature' (Atsma 2011) and is probably the original prototype for the 'Mother Earth' archetype. Donald Kalsched and Alan Jones (1986) write: 'In the beginning of many creation myths is an image of an original state of perfection, wholeness, and beatific containment. This is often represented as a containin circle, cave, pool, or sphere. The predominant archetypal symbol is that of the primordial Earth Goddess - the Great Mother with her nourishing and protective
womb'. 
Once again, he calls to the earth as his mother, aware that in this darkness he will find sanctuary, as a child in distress returns to the mother in its time of need. In the darkness of the cavern in which he finds himself, with a broken arm and aching head and hip from the fall, he also finds an underwater stream that quenches his thirst. At first he feels that he deserves to die within the same space where Gelluk's body lies; he sees this as a kind of justice: 'It was only fair that he should die here with the man he had killed. It was right' (Le Guin 2001:100). This kind of justice would answer a patriarchal system based on rules. Carol Gilligan shows how men and women tend to perceive morality and justice differently. She argues, in terms that are germane to our research, that women make moral choices based on relationship, whilst men focus on systems. ${ }^{9}$ As Otter lies in the cave, shivering and in pain, however, 'something in him ached, not the sharp body pain, a long ache, lifelong' (Le Guin 2001:100). Otter has experienced life. He knows, because of the relationships he has had with Anieb and Elehal, what it is to love, to trust, to give of himself to others. It is this very humanness in him that is reawakened in the depths of the earth whom he has called mother and that encourages him to seek life. In the dark tomb where he could die, he finds life.

Little by little, stumbling through the dark passageways of the underground caverns, Otter realises that they are not the fantastical 'marvelous red palace of Tinaral's [Gelluk's] vision, mystical silver runes on high branching columns. It was only the earth, only dirt, rock, water' (Le Guin 2001:101). Gelluk had imagined all kinds of exotic underground caverns, but the earth is ordinary, plain and yet elemental. Gelluk, in common with mages such as Ivory, admires the meretricious and glamorous aspects of magic. This traditional view of magic as something to thrill and attract attention is opposed to women's ordinary, plain earth magic, and reflects the underlying values that motivate patriarchal desire for power and position. Women (and men who do not subscribe to patriarchal values) engage with the grubbier side of life. Women's magic is neither sparkling nor sensational, yet it contains the substance of life: the soil of the earth.

The passages through which Anieb leads Otter are not a regular and ordered system of corridors, such as might link a building, even one as large as a palace or castle. They are an integrated labyrinthine system, a complicated, irregular structure that is part of the earth itself and not easily mastered. This brings us to a deeper consideration of the labyrinth, which in Le Guin's Earthsea is situated underground, and is, literally in The tombs of Atuan, a tomb, which also becomes a representation of women's power.

\section{The labyrinth}

The practice of building labyrinths dates from approximately 4000 BCE (Fisher 2006:7). Becker (1994) records that:

labyrinths were originally two-dimensional, more or less symmetrical patterns whose middles were connected to the

9.Gilligan's interest in women's greater investment in relationships than in 9.Gilligan's interest in women's greater investment in relationships than in
achievement follows the work of Nancy Chodorow (1978) in The reproduction of mothering. exit by disproportionately long, yet clear-cut paths that neither crossed nor left open the possibility of a choice. (p. 170)

A labyrinth would lead the walker from the entrance to its centre whilst covering the maximum distance. It is not to be confused with a maze: Tony Ullyatt $(2010,2011)$ expertly explains the differences between labyrinths and mazes in terms of both structure and function, although some writers, and many dictionaries, use the words interchangeably. A maze is often three-dimensional and multicursal, making it difficult for the walker to find the way out. In addition, whilst mazes are designed to disorientate people, labyrinths are traditional aids to spiritual transformation and union with the divine (Artress 2006; Labyrinth Society 2013). Penelope Doob (1990) equates labyrinths and mazes, discussing them both as structures that disorientate the wanderer. By contrast, we distinguish between mazes, which are generally unicursal, above-ground, two-dimensional structures, which may occasionally lead underground for a short distance, and Le Guin's labyrinths, which are always three-dimensional underground constructions. J.C. Cooper (1978) notes that the labyrinth is:

a highly complex symbol. ... The symbolism of the labyrinth is variously suggested as the return to the Centre; Paradise regained; attaining realization after ordeals, trials and testing; initiation, death and rebirth and the rites of passage from the profane to the sacred; the mysteries of life and death; the journey of life through the difficulties and illusions of the world to the centre as enlightenment or heaven; a proving of the soul; the path of travel and escape to the next world (this world being easy to enter, but once entered into difficult to leave); a knot to be untied; danger; difficulty; fate. (pp. 92-93)

Likewise, Doob (1990:23) observes that they have a sacral function 'as protection, to impede access to sacred places or to deny a quick escape to thieves or the sacrilegious'. Labyrinths in literature ${ }^{10}$ often represent fears of being trapped and confined (Miller 2011:27). For example, Greer Gilman uses labyrinths in her fiction as a motif for young girls' quest for identity. Many labyrinth stories are set during puberty, and the labyrinth's convolution and inwardness make it an analogue for a woman's genitalia. Le Guin's labyrinths, like her caves, are places that resonate with the subtlety and mysticism of female power, but Le Guin adds to this the connotations of getting lost and finding one's way, which are associated with labyrinths and mazes, as metaphors for self-transformation. There are two labyrinths in Earthsea: the one in 'The finder' situated in Havnor and the one at The Place in Atuan. In her depiction of labyrinths, Le Guin brings together the feminised meanings of underground space, which we have previously explored, with the sacral overtones of labyrinths above ground, making the labyrinth a powerfully ambivalent site. Those who, like Gelluk and Kossil, seek power and possessions, lose their way and find doom in the labyrinths, but those who seek a deeper knowledge of themselves and others find that labyrinths can lead to freedom.

10.See, for instance, Alice's long journey underground in Lewis Carroll's (1992) Alice's Adventures in Wonderland and Mrs Moore's experience in the cave in E.M. Foster's ([1924] 2011) A passage to India. More recently, the trope has been found in films such as Jim Henson's (1986) Labyrinth and Guillermo Del Toro's (2006) Pan's
Labyrinth. 
In common with the conventional presentation of labyrinths, those in Earthsea are accessed by descending into darkness and those who enter illegally are doomed to get lost. Even Kossil, who desecrates the labyrinth, is afraid, as Tenar senses (Le Guin 1993a:200). But the labyrinths can also be places of life and transformation through the mysticism of female power. Mary Daly (1988) identifies 'labrys' as one of the origins of the word 'labyrinth'11.

derived from ancient Gr[eek] Labrys - ancient Cretan double ax sign of imperial might - sign of gynocratic power in Crete as it was among the Lycians, the Lydians, the Amazons, the Etruscans, and even the Romans ... found in the graves of Paleolithic women of Europe, buried 50000 years ago. (p. 31)

Tenar only enters the labyrinth once she is on the verge of womanhood and it becomes the site of her individuation. Her subterranean meanderings entail learning its intricacies and finding her identity. Significantly, Ged breaks the taboo on men entering the undertomb and accepts the limitations that this imposes on his masculine powers (Le Guin 1993a:249). Unlike most men, and particularly the hierarchy of mages, Ged acknowledges the old powers, which are sacred to women. This points to his willingness to embrace feminine qualities, such as connection and relationship, enabling him to find the lost half of the Ring of Erreth-Akbe and reunite the broken rune for peace. The androgynous power of connection empowers him to restore Tenar's name in the labyrinth, in the Great Treasure Room: 'He raised his face to her. His expression was strange. "Take care, Tenar," he said' (Le Guin 1993a:256). Tenar has delayed visiting this room until Ged enters the tombs, and then she finds that the treasure it holds is her self. Although Gilman is disappointed that Le Guin requires Tenar to encounter a man before she can find her identity and freedom, we see this as consistent with Le Guin's project of bridging the gender divide. Significantly, Tenar finds her own womanly power underground, in the great treasure room, once Ged has restored her name to her. At this point she holds power over both their lives because only she knows the way out of the labyrinth. When she chooses to trust him, they are both able to escape being crushed. Crucially, neither can escape alone; they must trust each other, or die. It is equally important that the woman leads the way (as Anieb did for Otter).

Doob (1990:24) uses 'labyrinth' to mean a structure that misleads the walker. She explains that a labyrinth is confusing and dangerous for those without a guide, 'allowing wrong choice and perpetual entrapment', because 'its structural complexities, its vast array of halls, crypts, corridors and winding paths' (ibid:24) make the labyrinth difficult to enter and leave. Demonstrating her conflation of the terms 'maze' and 'labyrinth', she says, however, that 'the maze's ability to bewilder depends on one's point of view' (p. 24). Tenar learns to know her way through what seems to be an endless sameness in the labyrinth (Le Guin 1993a:211), because

11.The word 'labrys' is not unanimously accepted as the origin of the word 'labyrinth'. This word is usually associated with one of the chambers in the multi-storied Palace at Knossos. The Palace as a whole was so complex that it reminded archaeologist Arthur Evans of the labyrinth of Greek myth (Ancient-Greece.org n.d.). Other Arthur Evans of the labyrinth of Greek myth (Ancient-Greece.org n.d.). Other
writers trace the etymology of the word 'labyrinth' to the Greek 'labyrinthos', which is not related to the axe, but to the maze (see Kern 2000:25). 'once you ... see the labyrinth whole, then, elaborate chaos is transformed into pattern' (Doob 1990:24). This enables her to lead Ged out when the tombs are collapsing (Le Guin 1993b:227).

Tenar's knowledge of the labyrinth echoes Daly's (1988:31) definition: 'Labyrinth - true pathway of the Metaphysical Journey of Exorcism and Ecstasy; leading into and through the Background'. Daly (1988) describes the background as:

the realm of Wild Reality; the homeland of women's Selves and of all the Others; the Time/Space where auras of plants, planets, stars, animals and all Other animate beings connect. (p. 63)

Tenar is able to connect with others by exorcising her belief in the evil of the Nameless Ones. Ironically, the impotent power she had in their service, which had been corrupted by its manipulation to the will of men, is her true power. She discovers 'ecstasy' as she encounters the homeland of her self and is empowered through connection, rather than submitting to the male symbolic order.

The labyrinth in The tombs of Atuan is entered only through the undertomb and is surrounded by The Place, in the middle of a desert. Men are forbidden to enter the place and are strictly prohibited from going into the undertomb. The labyrinth is, therefore, sacrosanct to women, and especially to the high priestess of the nameless ones. Descending into the labyrinth is analogous to plumbing the unconscious, which possesses all the qualities of irrationality that are typically associated with women. The secrets of the labyrinth are known only by the high priestess, and she reveals them to only one other woman before she dies, to be given back when she returns in her new incarnation. The labyrinth is circuitous and in many places recursive, with no landmarks. It is obscure, a place of secrets and hidden treasure, a place of terror connected with the old powers of the earth. So-called masculine rationality and linear logic do not work in the labyrinth, where there are no straight lines, centre or goal. All the paths through the labyrinth are circular, evoking the cyclical patterning of women's time (Kristeva 1986:192).

Ironically, the nameless ones, who preside over the tombs, are akin to the old powers of the earth, which protected Dulse in 'The bones of the earth' and Otter in 'The finder'. The tombs are ostensibly sacred to women's power, but they have been perverted by the Godking to serve men's power and so have lost their real ability to provide women with the power they should possess. The evil centres on the perverted psyche of Kossil. Kossil proves that not all women are inherently benevolent or nurturing. She has no sense of the mysticism and sacredness of women's power. We see Kossil's insanity when she intrudes into the sacred spaces of Tenar's secrecy and rapes her vulnerability. She enjoys Tenar's pain and mocks her fear, making the labyrinth unsafe for her. Kossil becomes a scavenger, preying on others, growing fat on her own cruelty and, instead of working together with the deities she claims to serve, eventually brings the labyrinth down upon herself (Le Guin 1993a:273). 
Kossil's egocentricity becomes her doom, but the labyrinth offers renewal to Ged and Tenar. Through their collaboration in the joining of the Ring of Erreth-Akbe in the treasure room of the tomb, the two are enabled to find freedom. This heralds the possibility of social healing and the emergence of life from the tomb. Tenar walks away from the tombs reborn, bearing her new name with dignity. She has found that the power of women, which Kossil sought to negate, lies in connection with others.

Years later, in Tehanu: The last book of Earthsea, when Ged has poured out his male magic to seal the hole caused by Cob, he learns that to be fully a man is to embrace that which he has always shunned - female sexuality. Le Guin (1993a) brings us back to the trope of the labyrinth:

'Tenar, my dear. Come on. Come with me.'

They were not at the fire. They were in the dark - in the dark hall. The dark passage. They had been there before. Leading each other, following each other, in the darkness underneath the earth.

'This is the way,' she said. (p. 645)

Our article has shown that Le Guin's subterranean spaces are redolent of the mysterious, unknown, possibly unknowable, ways and wizardry ${ }^{12}$ of women. Women's powers are directed towards collaboration, as Le Guin contends in 'Is gender necessary? Redux': 'the 'female principle' is, or at least historically has been, basically anarchic. It values order without constraint, rule by custom not by force' (Le Guin 1993b:163). Therefore, when men do not fear to enter underground spaces with women, when they do not seek to dominate or to rob them, then the possibility of new dialogue and discourse is opened, then there is space for transformation and social change. Men fear the tombwomb of women's magic as they fear their own death. Ged, however, has had to confront his own death in the dry places. Ged's experience of death means that he is able to lay aside the meaning of power he has learned from the male symbolic order and revalue the power of being fully human.

Tenar and Ged come together fully as man and woman, giving themselves to one another freely and openly in a marriage of equal minds, hearts and bodies. Le Guin explains that in her books: 'the sex itself is seen as a relationship rather than an act' (Le Guin 1993b:138, original emphasis). This is in keeping with Gilligan's (1993:17) insight that 'the discovery now being celebrated by men in mid-life of the importance of intimacy, relationships, and care is something that women have known from the beginning'. Tenar exemplifies Gilligan's (1993:17) observation that 'women not only define themselves in a context of human relationship but also judge themselves in terms of their ability to care'. Ged and Tenar have faced danger and death together and are aware of the uniqueness of the other before them. Each has loved the other through years, but has been prevented from expressing it. As in the tombs, after confronting death, they can find life together and confirm it through their sexual union.

12.The word 'wizardry' is used deliberately here, although 'wizard' is a term that is usually reserved for men in Earthsea, to signal our recognition of the parity of women's and men's magic.

\section{Conclusion}

As Penelope Doob (1990) has pointed out, the labyrinth in classical Greek mythology was a space that empowered a woman (Ariadne) at the same time as it claustrophobically entrapped a man (Daedalus). Miller's (2011) article gestures towards the way in which the labyrinth evokes the moment of hesitation between girlhood and womanhood in women's maturation, but does not fully explore this connotation. Le Guin's labyrinth in The tombs of Atuan is a symbol of Tenar's liminal stage of development, but when Le Guin revisions Earthsea in Tehanu, underground spaces, including the labyrinth, are re-imagined. Tenar now becomes an Ariadne figure, guiding Ged out of the labyrinth of his own apathy, and reaffirming the own life-affirming choice they made together in the imploding labyrinth of the tombs of Atuan. This time, again, the journey through the labyrinth is a transforming one, enabled by the power of a woman who has experienced unconscious underground forces, which animate Moss's 'witchery'. Le Guin has effectively revisioned the traditional tropes of the cave and the labyrinth as being both claustrophobic and mystical. By enhancing their gender dimensions she has reimagined them as spaces of transformation and relationship for women and men.

\section{Acknowledgements Competing interests}

The authors declare that they have no financial or personal relationship(s) that may have inappropriately influenced them in writing this article.

\section{Authors' contributions}

L.D. (University of South Africa) came up with the initial concept of analysing underground and labyrinthine spaces in Ursula Le Guin's Earthsea texts and also wrote an initial rough draft of the article. D.B. (University of South Africa) was responsible for restructuring the material and adding theoretical and other sources in order to bring it in line with acceptable standards of scholarly research. Both L.D. and D.B. made conceptual contributions to drafting, refining and polishing the article.

\section{References}

Ancient-Greece.org n.d., Knossos, viewed 14 February 2014, from http://www. ancient-greece.org/archaeology/knossos.html

Anzaldúa, G.E., 1987, Borderlands/La frontera: The new Mestiza, Aunt Lute Books, San Francisco.

Artress, L., 2006, Walking a sacred path: Rediscovering the labyrinth as a spiritual practice, Riverhead Trade, New York.

Atsma, A.J. (ed.), 2011, Gaia Mother Nature, in Protogenos, viewed 03 June 2013, from http://www.theoi.com/Protogenos/Gaia2.html

Becker, U., 1994, The continuum encyclopedia of symbols, Continuum, New York/ London.

Butler, J., 1990, Gender trouble, Routledge, New York.

Carroll, L., 1992, Alice in Wonderland, 2nd edn., W.W. Norton \& Co., New York.

Chodorow, N., 1978, The reproduction of mothering: Psychoanalysis and the sociology of gender, University of California Press, Berkeley/ Los Angeles.

Clarke, A.M., 2010, Ursula K. Le Guin's journey to post-feminism, McFarland, Jefferson. Cooper, J.C., 1978, An illustrated encyclopaedia of traditional symbols, Thames \& Hudson, London. 
Daly, M., 1988, Webster's first new intergalactic Wickedary of the English language, The Women's Press Limited, London.

Del Toro, G. (dir.), 2006, Pan's labyrinth (film), Estudios Picasso, Madrid.

Donaldson, E., 2012, 'A chronology of her own: The treatment of time in selected works of second wave feminist speculative fiction', unpublished D.Litt thesis, Dept. of English, University of Pretoria.

Doob, P.R., 1990, The idea of the labyrinth from classical antiquity through the Middle Ages, Cornell University Press, Ithaca.

Douglas, L.C., 2012, When the great male fantasy fails: The revisioning of power in Ursula Le Guin's fantasy worlds, unpublished MA dissertation, Dept. of English, Ursula Le Guin's fantasy wor
University of South Africa.

Douglas, M., 1966, Purity and danger, Routledge and Kegan Paul, London. http:// dx.doi.org/10.4324/9780203361832

Fisher, A., 2006, The amazing book of mazes, Thames \& Hudson, London.

Forster, E.M., [1924] 2011, A passage to India, Hodder \& Stoughton, London.

Freud, S., 1913, The interpretation of dreams, transl. A.A. Brill, Macmillan, New York. http://dx.doi.org/10.1037/10561-000

Gilligan, C., 1993, In a different voice: Psychological theory and women's development, Harvard University Press, Cambridge.

Gilman, G., 2009, 'Girl, implicated: The child in the labyrinth in the fantastic', Journa of the Fantastic in the Arts 20(2), 199-203.

Haraway, D., 1985, 'A cyborg manifesto', in N. Spiller (ed.), The cyber reader: Critical writings for the digital era, pp. 108-115, Phaidon Press, New York.

Henson, Jim (dir.), 1986, Labyrinth (film), Henson Associates and Lucasfilm, Los Angeles/San Francisco.

Hutcheon, L., 1993, The politics of postmodernism, Routledge, London.
Kalsched, D. \& Jones, A., 1986, Myth and psyche: The evolution of consciousness, in C.G. Jung Goundation, viewed 07 August 2013, from http://www.cgjungny.org

Kern, H., 2000, Through the labyrinth: Designs and meanings over 5000 years, Prestel, Munich/London/ New York.

Kristeva, J., 1986, The Kristeva reader, T. Moi (ed.), Routledge, New York.

Labyrinth Society, 2013, Learn about labyrinths, viewed 05 June 2013, from http:// labyrinthsociety.org/about-labyrinths

Le Guin, U.K., 1993a, The Earthsea quartet, Penguin, Harmondsworth.

Le Guin, U.K., 1993b, The language of the night: Essays on fantasy and science fiction, S. Wood \& U.K. Le Guin (eds.), HarperPerennial, New York.

Le Guin, U.K., 2001, Tales from Earthsea, Harcourt, New York.

Le Guin, U.K., 2002, The other wind, Orion Children's Books, London.

Miller, T.S., 2011, 'The two kings and the two labyrinths: Escaping escapism in Henson's Labyrinth and Del Toro's Laberinto', Extrapolation 52(1), 26-50. http:// dx.doi.org/10.3828/extr.2011.52.1.3

Rawls, M., 2008, 'Witches, wives and dragons: The evolution of the women in Ursula K. Le Guin's Earthsea - An overview', Mythlore 26(3/4), 129-149.

Rich, A., 1995, Of woman born, Norton, New York.

Stoltzfus, B., 1981, 'Robbe-Grillet's labyrinths: Structure and meaning', Contemporary Literature 22(3), 292-307. http://dx.doi.org/10.2307/1208281

Ullyatt, A.G., 2010, 'An abstract model of conjecturality': Prolegomenon to an understanding of labyrinths and mazes as metaphors', Journal of Literary Studies 26(4), 73-97. http://dx.doi.org/10.1080/02564718.2010.529310

Ullyatt, A.G., 2011, “"Gestures of approach": Some initial reflections on liminality and labyrinths', Literator 32(2), 103-134. http://dx.doi.org/10.4102/lit.v32i2.14

Urban Dictionary, 2006, la petite mort, viewed 26 May 2013, from http://www. urbandictionary.com/define.php?term=la+petite+mort 